\title{
Effect Of Motivation And Organizational Culture On Employees Performance Through Organizational Commitments At Cooperative In Badung Regency
}

\author{
Putu Ngurah Suyatna Yasa and Made Ayu Sancita Dewi \\ \{info@warmadewa.ac.id\} \\ Universitas Warmadewa, Denpasar, Indonesia
}

\begin{abstract}
This study aims to determine and explain the role of organizational commitment in mediating the effect of motivation and organizational culture on the performance of employees at Cooperative in Badung regency. This study uses a quantitative type survey method with 97 people as sample calculated by slovin formula. To determine the sample size used probability sampling method. The data used in this study are primary and secondary data both quantitative and qualitative data. Data analysis conducted in this study are descriptive analysis and inferential analysis methods. The results showed that motivation had a negative and not significant effect on employee performance as well as the organizational culture that had a negative and a not significant effect on the performance of employees at the Cooperative in Badung regency. However, in terms of organizational commitment, this study found a positive and significant influence on employee performance and fostered a positive motivation. The organizational commitment is the perfect mediation in mediating the organizational culture of employee performance at the Cooperative in Badung regency.
\end{abstract}

Keywords: Cooperative, Motivation, Organizational Culture, Organizational Commitment, Employee Performance

\section{Introduction}

Employees who have a high performance will definitely facilitate the organization in achieving their goals. Employee performance is often interpreted as an achievement of tasks, where employees in working must be in accordance with a work program of the organization to show the level of organizational performance in achieving the vision, mission, and goals of the organization [1]. Employee performance is influenced by motivational factors, organizational culture and organizational commitment [2]. Motivation is defined as a process that describes a person's strength, direction and perseverance in an effort to achieve goals. In a previous research found that work motivation has a significant effect on organizational commitment and work motivation has a significant effect on employee performance [3]. [4] also found that work motivation with organizational commitment mediation had a positive and significant effect on employee performance, but different results show that partially of work 
motivation did not affect employee performance while organizational commitment negatively affected employee performance [5]. The results of the study indicate the effect of motivation on inconsistent performance means that it needs to be examined again by considering other factors such as organizational culture. Organizational culture and performance satisfaction have a significant influence on commitment and organizational culture, job satisfaction and commitment as predictors for employee performance. The motivation and organizational culture have a significant effect on performance [6]. Moreover, there is a significant influence between culture to organizational commitment, organizational commitment to performance, and organizational culture to performance. Employee commitment also has a positive effect on employee performance. In the study by [7] found that organizational culture and organizational commitment had an effect on performance with mediation of satisfaction because a low employee commitment could lead to a decrease in performance or reduced employee loyalty. Conversely, in a high employee commitment, employees will be more responsible for their work.

Based on the background aforementioned, accordingly the influence of motivation, organizational culture and organizational commitment is inconsistent, which means that it is important to be examined again by taking the object of study at cooperatives in Bali. Data of Cooperative performance in Bali on 2017 are presented in the following table:

Table 1. Data of Cooperative Development based on Regency/City

\begin{tabular}{|c|c|c|c|c|c|c|c|}
\hline \multirow[t]{2}{*}{ No } & \multirow[t]{2}{*}{ Regency /City } & \multirow[t]{2}{*}{ Active } & \multirow{2}{*}{$\begin{array}{c}\text { Non } \\
\text { Active }\end{array}$} & \multirow[t]{2}{*}{ Total } & \multicolumn{3}{|c|}{ Members } \\
\hline & & & & & Male & Female & Total \\
\hline 1 & Buleleng & 279 & 51 & 330 & 45.075 & 18.912 & 63.987 \\
\hline 2 & Jembrana & 253 & 8 & 261 & 34.284 & 20.511 & 54.795 \\
\hline 3 & Tabanan & 448 & 107 & 555 & 65.605 & 29.213 & 94.818 \\
\hline 4 & Badung & 482 & 121 & 603 & 93.937 & 43.050 & 136.987 \\
\hline 5 & Denpasar & 1062 & 2 & 1064 & 83.351 & 55.070 & 138.421 \\
\hline 6 & Gianyar & 973 & 238 & 1211 & 163.206 & 38.973 & 202.179 \\
\hline 7 & Bangli & 205 & 22 & 277 & 56.420 & 5.050 & 61.470 \\
\hline 8 & Klungkung & 115 & 7 & 122 & 31.491 & 17.349 & 48.840 \\
\hline 9 & Karangasem & 307 & 3 & 310 & 72.494 & 37.413 & 109.907 \\
\hline \multirow[t]{6}{*}{10} & Nivo Province & 159 & 8 & 167 & 90.745 & 57.794 & 148.539 \\
\hline & Total & 4283 & 567 & 4850 & 736.608 & 323.335 & 1.059 .943 \\
\hline & Amount since & 4472 & 523 & 4995 & 695.439 & 319.196 & 1.014 .635 \\
\hline & December 2016 & & & & & & \\
\hline & Development & (189) & 44 & (145) & 41.169 & 4.139 & 45.308 \\
\hline & $\%$ & $-4,23 \%$ & $8,41 \%$ & $-2,90 \%$ & $5,92 \%$ & $1,30 \%$ & $4,47 \%$ \\
\hline
\end{tabular}

Source: BPS Province Bali 2017

Based on table 1, the number of cooperatives that are actively decreasing and those that are not active increases as well as the total cooperatives. This means that there are indications that the cooperative has not been optimal, it caused by a decrease in the performance of cooperative employees. Based on the issues, this study aims to determine and explain the role of organizational commitment in mediating the effect of motivation and organizational culture on the performance of employees at Cooperative in Badung regency. Performance is very important for every organization, the factors that determine performance are motivation, organizational culture, and organizational commitment. The relationship among the variables is presented in the following: 


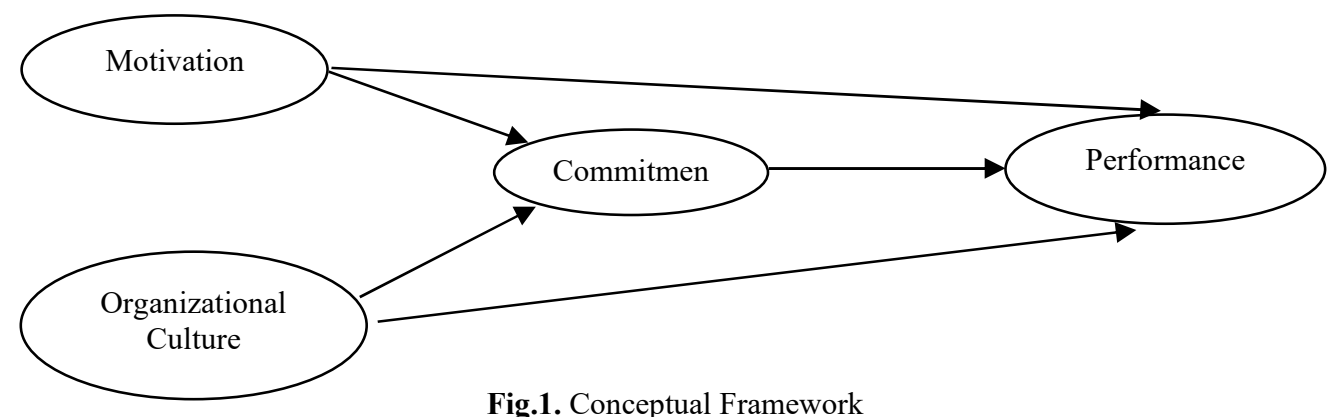

Concerning the background of the problem, formulation of the problem, and the research concept above, the hypothesis that developed in this study are:

H1: Work motivation has a significant effect on employee performance.

H2: Organizational culture has a significant effect on employee performance.

H3: Organizational commitment has a significant effect on employee performance.

H4: Motivation affects employee organizational commitment.

H5: Organizational culture has a significant effect on organizational commitment.

H6: Organizational commitment is able to mediate motivation on employee performance.

H7: Organizational commitment is able to mediate organizational culture on employee performance.

\section{Method}

This study uses a quantitative type survey method. The variables identified are exogenous and endogenous constructs. The sample in this study is Cooperative employees in Badung Regency determined by using probability random sampling. Sample calculation is done using the Slovin formula [8] amounted to 97 people. The validity test used is Person Correlation method through SPSS Version 21 program. To test the reliability of the questionnaire, the Cronbach Alpha technique was used [8]. Moreover, data analysis conducted in this study uses descriptive analysis and inferential analysis methods.

\section{Result And Discussion}

\subsection{Validity Test of Research Instruments}

The results of the validity test show that all indicators used to reflect the construct have a correlation value greater than 0.30 and significant at the level of significance 0.05 or 0.10 . 3.1.1 Validity Test of Motivation Variable (X1)

Table 2 Validity Test Results of Motivation Variable (X1)

\begin{tabular}{clcc}
\hline Variable & \multicolumn{1}{c}{ Statements } & Validity & Descriptions \\
\hline Motivation & $\begin{array}{l}\text { X1.1 I feel satisfied with the amount of salary, the bonus } \\
\text { that has been received } \\
\text { X1.2 I feel comfortable with safety and security facilities, }\end{array}$ & 0,705 & Valid \\
& & 0,785 & Valid \\
\hline
\end{tabular}




\begin{tabular}{|c|c|c|c|}
\hline Variable & Statements & Validity & Descriptions \\
\hline & $\begin{array}{l}\text { including social security, health benefits and health } \\
\text { insurance. } \\
\text { X1.3 I feel comfortable in interacting with others, } \\
\text { including by establishing harmonious working } \\
\text { relationships, the need to be accepted in groups and the } \\
\text { need to love and be loved. }\end{array}$ & 0,848 & Valid \\
\hline & $\begin{array}{l}\text { X1.4 I get awards based on ability, that are the need to be } \\
\text { respected and appreciated by other employees and leaders } \\
\text { for the work performance of each employee }\end{array}$ & 0,633 & Valid \\
\hline & $\begin{array}{l}\text { X1.5 I get a lot of interesting and challenging work, in } \\
\text { which I will mobilize my skills; and abilities. }\end{array}$ & 0,711 & Valid \\
\hline
\end{tabular}

Source: Data processed 2019

Based on table 3, shows that all indicators used to reflect the construct have a correlation value greater than 0.30 and significant at the level of significance of 0.05 , it means that all indicators show the valid results.

\subsubsection{Validity Test of Organizational Culture Variable (X1)}

Table 3. Validity Test Results of Organizational Culture (X2)

\begin{tabular}{clcc}
\hline Variable & \multicolumn{1}{c}{ Statements } & Validity & Descriptions \\
\hline $\begin{array}{c}\text { Organizational } \\
\text { Culture }\end{array}$ & $\begin{array}{l}\text { X2.1 There are beliefs and moral or ethical aspects that } \\
\text { are appreciated when working }\end{array}$ & 0,763 & Valid \\
& $\begin{array}{l}\text { X2.2 I have the desire to do or produce the best. } \\
\text { Including responsibility, discipline, and future } \\
\text { orientation. }\end{array}$ & 0,73 & Valid \\
$\begin{array}{l}\text { X2.3 I can be emulated and followed by other parties } \\
\text { because of a good and right actions and attitudes which } \\
\text { including the acting fairly, decisively, and wisely. } \\
\text { X2.4 I appreciate Human Resources as the company's } \\
\text { main asset and maintain their quality, respect, and } \\
\text { reward their work results. }\end{array}$ & 0,645 & Valid \\
\hline
\end{tabular}

Source: Data processed 2019

Based on table 4, the results of the validity test show that all indicators used to reflect the construct have a correlation value greater than 0.30 and significant at the level of significance of 0.05 , it means that all indicators show valid results.

\subsubsection{Validity Test of Organizational Commitments Variable (Y1)}

Table 4. Validity Test Results of Organizational Commitment (Y1)

\begin{tabular}{clccc}
\hline Variable & \multicolumn{1}{c}{ Statements } & Validity & Descriptions \\
\hline $\begin{array}{c}\text { Organizational } \\
\text { Commitment }\end{array}$ & $\begin{array}{l}\text { Y1.1 I am proud to be part of this organization } \\
\text { Y1.2 I like to boast this organization to people outside } \\
\text { this organization }\end{array}$ & 0,700 & Valid \\
& $\begin{array}{l}\text { Y1.3 I am very concerned about the fate of this } \\
\text { organization }\end{array}$ & 0,610 & Valid \\
$\begin{array}{l}\text { Y1.4 I am happy that I chose to work in this } \\
\text { organization }\end{array}$ & 0,600 & Valid
\end{tabular}




\begin{tabular}{|c|c|c|c|}
\hline \multirow[t]{3}{*}{ Variable } & Statements & Validity & Descriptions \\
\hline & $\begin{array}{l}\text { Y1.5 My values are same as the values of this } \\
\text { organization }\end{array}$ & 0,400 & Valid \\
\hline & $\begin{array}{l}\text { Y1.6 I am willing to work overtime for this } \\
\text { organization to succeed }\end{array}$ & 0,330 & Valid \\
\hline
\end{tabular}

Source: Data processed 2019

Based on table 5 , the results of the validity test show that all indicators used to reflect the construct have a correlation value greater than 0.30 and significant at the level of significant 0.05 , which has meaning that all indicators show valid results.

\subsubsection{Validity test of Performance Variable (Y2)}

Table 5. Validity Test Results of Performance Variable (Y2)

\begin{tabular}{clcc}
\hline Variable & \multicolumn{1}{c}{ Statements } & Validity & Descriptions \\
& & & \\
\hline Performance & Y2.1 I have technical skills to complete work on time & 0,800 & Valid \\
& Y2.2 I can complete the work carefully as expected & 0,870 & Valid \\
& Y2.3 I feel I have a responsibility for the work that is burden & 0,895 & Valid \\
& to me & & \\
& Y2.4 I can complete duties and fulfill their responsibilities & 0,901 & Valid \\
& with a time limitation & & \\
& Y2.5 I have good initiation to carry out new duties & 0,740 & Valid \\
\hline
\end{tabular}

Source: Data processed 2019

Based on table 6 , the results of the validity test show that all indicators used to reflect the construct have a correlation value greater than 0.30 and significant at the level of significance of 0.05 , which has meaning that all indicators show valid results.

\subsection{Reliability Test of Research Instruments}

The reliability test results of the research instrument are shown in Table 6. The results of the test show that all indicators used reflecting the constructs studied with Cronbachs Alpha value is greater than 0.70 which means that all indicators measured are reliable.

Table 6. Reliability Test Results

\begin{tabular}{clcc}
\hline No & \multicolumn{1}{c}{ Constructions } & Alpha Cronbach's & Descriptions \\
\hline 1 & Motivation (X1) & 0,787 & Reliable \\
2 & Organization Culture (X2) & 0,779 & Reliable \\
3 & Organization Commitment (Y1) & 0,707 & Reliable \\
4 & Performance(Y2) & 0,814 & Reliable \\
\hline
\end{tabular}

Source: Data processed 2019

\subsection{Effects of Motivation on Employee Performance}

Based on the results of testing regarding the effect of motivation on employee performance shows that motivation has a negative and not significant effect on employee performance, this means that the lower the motivation for employee performance is high, the negative relationship can be caused by motivation measured by intrinsic or extrinsic motivation such as intrinsic motivation causing employees to interact can determine the performance. This study is contrary with the previous study which found that it has a positive and significant effect on 
the performance of employees of Regional Companies of the Rural Bank (Bpr) of Bank Lamongan (Akbar et al, 2017).

\subsection{Effect of Organizational Culture on Employee Performance}

The effect of negative and not significant organizational culture on employee performance means that the stronger the organizational culture the lower the employee's performance. Organizational culture is reflected by indicators of trust and moral or ethical aspects that are valued when working. The effect of organizational culture that is not significant on performance is caused by organizational commitment. The results of this study are not supported by the results of previous studies which found that organizational culture has a positive and significant effect on organizational commitment and employee performance in the Breadfruit and Turpentine of Perum Perhutani Gondorukem and Independent Business Units in Gondorukem and Turpentine II, Ponorogo [2].

\subsection{Effect of Organizational Commitment on Employee Performance}

Based on the results of testing organizational commitment to employee performance shows that organizational commitment has a positive and significant effect on employee performance. This means that the employees who have a high and strong commitment will produce a good performance. In this study the dominant organizational commitment explained by indicators of employee is proud to be part of the organization, it has an outer loading of 0.73 and indicators of employees like to boast this organization to people outside this organization with an outer loading of 0.62 . Considering the characteristics of the respondents who were sampled in this study, it was dominated by employees aged $20-30$ years by $42 \%$, such ages were still classified as productive age and had a high commitment to advance the goals of the organization. These results are supported by previous study which found that organizational commitment has a positive and significant effect on employee performance at PT. Sido Muncul, Kaligawe Semarang [10].

\subsection{Effect of Motivation on Organizational Commitment}

Based on the results of the testing regarding the effect of motivation on organizational commitment, it shows that motivation has a positive and insignificant effect on organizational commitment. This means that the higher the employee motivation the stronger the organizational commitment of employees at the Cooperative in Badung Regency. In this research the most dominant motivation is explained by indicators of employee feel comfortable interacting with others, by establishing a harmonious working relationship, with an outer loading of 0.74 and getting lots of interesting jobs in which employees will deploy their own skills with an outer loading of 0,60 . Having a high commitment can be seen from the organizational commitment described with the indicators of employee proud to be part of the organization, it has an outer loading of 0.73 and indicators of employees like to boast this organization to people outside of this organization with an outer loading of 0.62 . Fortunately, the results of this study are supported by the results of previous studies [4] found that motivation has a positive and significant effect on organizational commitment at PLN Gianyar Rayon.

\subsection{Effect of Organizational Culture on Organizational Commitments}

Based on the results of testing regarding the effect of organizational culture on organizational commitment, it shows that organizational culture has a positive and significant effect on organizational commitment. This means that the higher the culture in an organization, the employee has a strong commitment to the organization. In this study the dominant organizational culture is explained by employee indicators the existence of trust and 
moral or ethical aspects are valued when working with an outer loading of 0.70 and employees have the desire to do or produce the best including: responsibility, discipline, and future orientation with outer loading of 0.60 . This research is supported by previous study which found that organizational culture has a significant effect on employee organizational commitment at the Batu City Education Office [11].

\subsection{Role of Organizational Commitment in Mediating Motivation on Employee Performance \\ Employees who are highly motivated will also have a high commitment to the company. Employees who are given encouragement will feel cared for, appreciated, and feel involved in organizational activities, then will grow a commitment to the organization. The results of the study show that work motivation with the mediation of organizational commitment had a positive and significant effect on the performance of employees of PLN Gianyar Rayon in Gianyar Regency [4].}

\subsection{Role of Organizational Commitment in Mediating Organizational Culture of Employee Performance. \\ Organizational commitment is a perfect mediation in mediating organizational culture on performance, it has meaning that a good organizational culture affect employees to have strong organizational commitment and produce good performance. The results of this study are supported by the results of previous studies [10] found that organizational culture has a positive and significant effect on organizational commitment, organizational commitment has a positive and significant effect on employee performance, organizational culture has a positive and significant effect on the performance of employees of PT Sido Muncul, Semarang.}

\section{Conclusions}

Based on the descriptions and results of the study, some conclusions can be made as follows:

1. Motivation has a negative and not significant effect on employee performance at the Cooperative in Badung Regency. This means that the lower the motivation the more performance increases.

2. Organizational culture has a negative and not significant effect on employee performance at the Cooperative in Badung Regency. This means that the organizational culture of the Cooperative is not good enough, but the employees produce good performance.

3. Organizational commitment has a positive and significant effect on employee performance at the Cooperative in Badung Regency. This means that strong organizational commitment at the Cooperative in Badung Regency has a good impact on improving employee performance.

4. Motivation has a positive and not significant effect on employee organizational commitment at the Cooperative in Badung Regency. This means that the better the motivation, the stronger the organizational commitment.

5. Organizational culture has a positive and significant effect on organizational commitment at the Cooperatives in Badung Regency. This means that a good organizational culture can affect employees to commit to the Cooperative. 
6. Organizational commitment is not able to mediate the effect of motivation on employee performance at the Cooperative in Badung Regency. This means that the effect of motivation on employee performance is not able to be delivered properly by organizational commitment.

7. Organizational commitment is a perfect mediation in mediating organizational culture on employee performance at the Cooperative in Badung Regency. This means that the effect of organizational culture on employee performance is delivered very well by organizational commitment.

\section{References}

[1] Sidanti, "Pengaruh Lingkungan Kerja, Disiplin Kerja dan Motivasi Kerja terhadap Kinerja Pegawai Negeri Sipil di Sekretariat DPRD Kabupaten Madiun," J. JIBEKA Progr. Stud. STIE Dharma Iswara Madiun, 2015.

[2] Usmany, "Pengaruh Budaya Organisasi terhadap Komitmen Organisasional dan Kinerja Karyawan,” J. Adm. Bisnis Fak. Ilmu Adm. Univ. Brawijaya Malang, 2016.

[3] Sunuharyo, "Pengaruh Motivasi Kerja terhadap Komitmen Organisasional dan Kinerja Karyawan (Studi pada Karyawan Bank BRI Cabang Kawi Malang)," J. Adm. Bisnis Fak. Ilmu Adm. Univ. Brawijaya Malang, 2016.

[4] Suarjana, "Pengaruh Motivasi Kerja dan Kepuasan Kerja terhadap Komitmen Organisasi serta dampaknya terhadap kinerja pegawai PLN Rayon Gianyar di Kabupaten Badung," J. Bisnis dan Kewirausahaan, 2016.

[5] Prasetya, "Analisis Pengaruh Motivasi Kerja, Komitmen Organisasi dan Kepemimpinan Terhadap Kinerja Karyawan (Studi Pada Karyawan Gudang Snack Semarang)," J. Progr. Res. Manaj. Univ. Dian Nuswantoro Semarang, 2015.

[6] Saifudin, "Pengaruh Motivasi, Komitmen, Lingkungan Kerja dan Stres Kerja terhadap Kinerja Pegawai Nergeri Sipil di Rumah Sakit Daerah Madani Provinsi Sulawesi Tengah,” J. Katalogis Progr. Stud. Magister Manaj. Pascasarj. Univ. Tadulako, 2017.

[7] Burhan and et al, "Pengaruh Budaya Organisasi dan Komitmen Organisasi terhadap Kinerja Karyawan dengan Mediasi Kepuasan Kerja pada PT BPR Setia Karib Abadi Semarang,” J. Soc. Polit. Univ. Diponegoro, 2013.

[8] Umar, Riset Pemasaran dan Perilaku Konsumen. Jakarta: Gramedia Pustaka Utama, 2003.

[9] Akbar and et al, "Pengaruh Kompensasi dan Motivasi Kerja terhadap Kinerja," Fak. Ilmu Adm. Universitas Brawijaya Malang, 2017.

[10] Taurisa, "Analisis Pengaruh Budaya Organisasi dan Kepuasan Kerja terhadap Komitmen Organisasional dalam meningkatkan Kinerja Karyawan (Studi pada PT Sido Muncul Kaligawe Semarang),” J. Bisnis dan Ekon. Progr. Magister Manaj. Univ. Diponegoro, 2012.

[11] Mustikasari, "Pengaruh Budaya Organisasi terhadap Komitmen Pegawai Dinas Pendidikan," $J$. Manaj. Pendidik. Univ. Negeri Malang, 2014. 